\title{
Càries precoç de la infància: de la prevalença a la prevenció
}

\author{
Anna Verdegal Burdeus (annavb@hotmail.com) \\ Centre de Salut Integrat de Benicarló
}

\section{Impacte de la càries en la societat actual}

La malaltia de càries dental és considerada per l'Organització Mundial de la Salut (OMS) un problema de salut pública perquè es tracta d'una patologia amb gran prevalença. Les malalties orals amb major prevalença són la càries i les periodontopaties. Segons l'OMS, la incidència de la càries en la població infantil a escala mundial és d'entre el 60\% i el $90 \%$, una dada gens negligible (OMS, 2004).

Segons mostra l'estudi epidemiològic de la Comunitat Valenciana de 2010, la prevalença de la càries temporal als sis anys és d'un $34,2 \%$ en xiquets de baix nivell socioeconòmic i d'un $20 \%$ en el nivell més alt. A més, en la dentició permanent, als dotze anys hi ha una prevalença de càries del $40,4 \%$ en la classe baixa i d'un $28,0 \%$ en la classe alta. Això demostra que el baix nivell socioeconòmic és un factor de risc de patir la malaltia de càries.

La malaltia de càries té una gran importància en tant que afecta la masticació, la fonació, la deglució i la digestió. També té un component psicològic relacionat amb els canvis estètics com a conseqüència de les lesions de càries, la pèrdua de peces dentàries, la modificació del perfil facial i l'afonament de galtes, així com del procés dolorós associat. En la nostra societat, la cara és un determinant clau en el procés d'integració social i, amb el somriure, exerceix a més un paper fonamental en la parla i la comunicació. Aquest deteriorament, junt amb la resta de factors, implica una menor qualitat de vida.

A la Comunitat Valenciana, coincidint amb la implantació del Programa de Salut Bucodental, es va realitzar el primer estudi de salut bucodental infantil en 1986, el qual va establir la situació de partida de la salut bucodental infantil al nostre territori. Des d'aleshores, la salut oral infantil ha millorat, i ha disminuït notablement la càries en la dentició permanent en totes les edats en el període 1986-2010. Així, als dotze anys s'ha observat una disminució del 70,2\% al 37,7\%, i als quinze anys ha disminuït del $82 \%$ al 42,6\%. No obstant això, en dentició temporal, la prevalença de càries roman estable al voltant del 30\% des de l'any 1998. Aquests valors són molt semblants als de l'última enquesta de salut oral realitzada a escala nacional $(33,3 \%)$, la qual cosa indica que és un dels factors de risc més importants per a patir càries en dentició permanent (Conselleria de Sanitat). Segons l'Enquesta de Salut Oral de Preescolars a Espanya, referida a l'any 2007, les càries no es distribueixen igual en tota la població infantil, de manera que el 2,7\% dels xiquets de tres anys acumulen el 47,8\% de les càries, i el 5,4\% dels xiquets de quatre anys n'acumulen el 50,7\% (Bravo i altres, 2007). 


\section{Relació de les càries amb malalties sistèmiques}

Hi ha una clara relació de les malalties bucodentals amb altres malalties cròniques més freqüents, amb les quals comparteixen alguns factors de risc, com ara les malalties cardiovasculars, les malalties respiratòries greus, la diabetis mellitus i el baix pes en nounats (Peña, 2008: 1). Més concretament, la malaltia periodontal es presenta com un factor de risc important que cal considerar en l'aparició de certes alteracions sistèmiques, com per exemple: resultats adversos de l'embaràs (part preterme i baix pes en nàixer), malalties cardiovasculars (endocarditis bacteriana, infart de miocardi, cardiopatia isquèmica i aterosclerosi), respiratòries (pneumònia bacteriana, bronquitis i malaltia pulmonar obstructiva crònica) i diabetis mellitus (Pretel-Tinoco i Chávez, 2013: 223). Herzberg i el seu equip (1992) van determinar que la sistèmica exposició hematògena als Streptococcus mutans de la cavitat oral és un iniciador potencial d'una endocarditis bacteriana. Una complicació d'una lesió de càries que porte a una patologia pulpar i a un abscés periapical pot ser responsable de l'inici i progressió de diverses malalties inflamatòries com ara l'artritis, l'úlcera pèptica i l'apendicitis (Moromi, 2004: 1). Matilla, per la seua banda (1989), va descriure la relació entre l'infart agut de miocardi i la infecció dental; processos infecciosos bucals com ara la periodontitis, abscessos periapicals i càries dental, amb molta freqüència estan presents en els pacients amb quadres clínics d'infart agut de miocardi. Moltes malalties tenen manifestacions de nivell oral que poden ser el primer signe de la seua presència. En són exemples el sarcoma de Kaposi i el limfoma no Hodgking com a primeres manifestacions de la sida (García Rodríguez i altres, 2006). D'altra banda, Clarke i el seu grup suggereixen que la càries precoç de la infància pot ser un marcador de risc per a l'anèmia per dèficit de ferro i que cal valorar els nivells de ferro en els xiquets que la pateixen (Clarke i altres, 2006).

\section{Càries i factors de risc}

\subsection{Definició de càries}

El terme càries s'utilitza indistintament per a denominar dos conceptes de la mateixa malaltia. D'una banda, es denomina càries la lesió, seqüela o conseqüència de la història natural de la malaltia que afecta la dent $\mathrm{i}$, d'una altra, la malaltia de càries pròpiament dita. La càries dental és una malaltia infecciosa, crònica, dinàmica i multifactorial que cursa amb la destrucció dels teixits durs de la dent com a conseqüència de la desmineralització, resultat de l'efecte dels àcids produïts pels bacteris cariogènics en metabolitzar els carbohidrats provinents de la dieta.

En la pràctica clínica se li ha donat fins ara molta més importància al resultat de la malaltia de la càries, és a dir, a la lesió de la càries. De fet, els pacients es preocupen per la lesió de la càries però desconeixen el que engloba la malaltia en si. Les últimes tendències apunten cap a una odontologia més preventiva, que insisteix a prevenir i controlar tots els conceptes de la malaltia i no sols la seqüela que produeix en la dentició. Segons aquesta tendència, no es tracta només d'eliminar la lesió de càries i substituir el teixit dentari per resines compostes, sinó que es tendeix a un diagnòstic de risc de càries que estudie els 
factors que la predisposen i que establisca unes pautes preventives. Per a establir el risc de càries s'han d'estudiar tots els indicadors de manera combinada, perquè estudiar només un indicador no és prou per a un diagnòstic complet.

\subsection{Càries precoç de la infància}

La càries precoç de la infància (CPI) és una forma particular de càries que afecta la dentició temporal dels lactants i dels xiquets en edat preescolar, de manera que compromet, generalment, diverses dents i provoca una destrucció ràpida del teixit dentari i la subsegüent infecció (Horowitz, 1998). En relació amb l'epidemiologia, la CPI es considera un problema de salut pública (Berkowitz, 2003), amb major prevalença als països en vies de desenvolupament i en estrats socials desfavorits dels països desenvolupats, com ara poblacions d'immigrants i minories ètniques (Milnes, 1996).

El terme càries precoç de la infància, que l'Associació Nord-americana d'Odontopediatria va adoptar l'any 2003 (AAPD, 2006), inclou la càries per biberó i la càries rampant. Es caracteritza per dents amb càries en xiquets i es defineix com la presència d'una o més dents amb càries, perdudes o obturades en pacients menors de 71 mesos (García-Suárez i Teja-Ángeles, 2008: 1). La CPI, a més de provocar dolor dental i posterior infecció, repercuteix també en l'alimentació, el creixement i el desenvolupament del xiquet, i pot afectar fins i tot el seu progrés acadèmic (Gussy i altres, 2006). A més, com que és un procés dolorós, repercuteix en alteracions del son.

El primer signe de càries és l'anomenada lesió de taca blanca, la qual té una aparença semblant al clarió i, en realitat, és una descalcificació reversible si es donen les condicions adequades. Amb la progressió de la càries, la lesió de taca blanca es converteix en una cavitació, d'un color marró clar; a mesura que la lesió avança en el temps, esdevé de color marró fosc i negre. La CPI té un patró semblant a altres formes de càries dental, però es diferencia en què és de progressió ràpida i converteix les lesions de taca blanca o descalcificacions en vertaderes cavitacions. Generalment, les lesions de taca blanca s'aprecien en la superfície vestibular dels incisius superiors temporals, en menors de tres anys. La CPI afecta generalment les dents superiors temporals. És indicatiu de CPI severa qualsevol signe de càries en superfícies llises en menors de tres anys. El patró característic
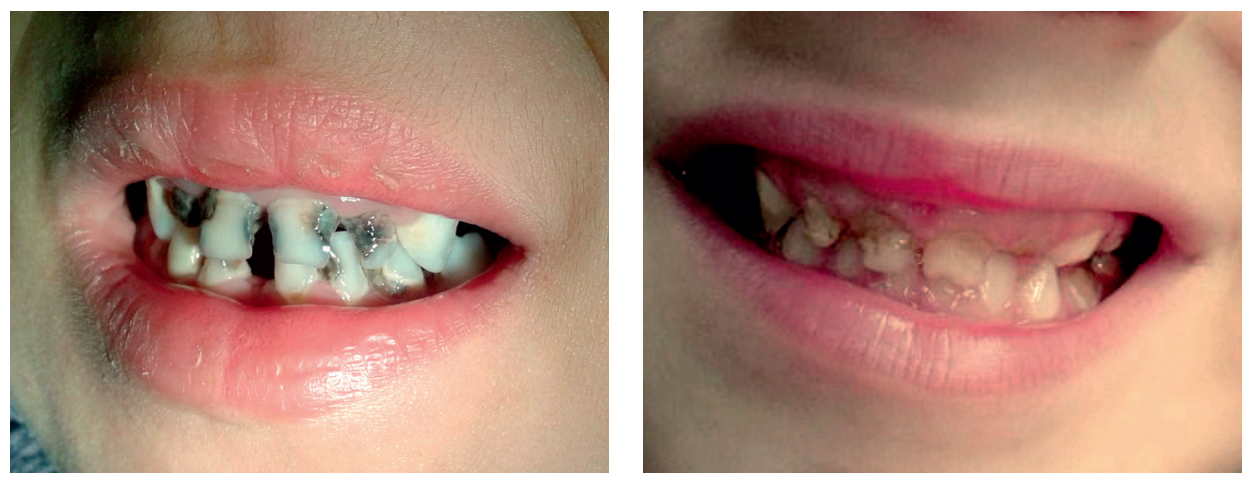

Fotos 1 i 2. Càries precoç de la infància. 
es relaciona amb la seqüència d'erupció de les dents, i per això afecta sobretot els incisius superiors temporals. A més, es relaciona amb la posició de la llengua durant l'alimentació, ja que aquesta protegeix els incisius inferiors, raó per la qual aquests no són afectats. Si no es prenen mesures per a frenar l'evolució de la malaltia, les següents dents afectades seran, per ordre, els primers molars, els segons molars i, finalment, els claus superiors. Només en casos molt severs seran afectades les dents del sector anteroinferior. La CPI afecta també l'estat general de la salut, de manera que els problemes bucodentals associats a la ingesta d'aliments i al dolor dental poden repercutir en la disminució del pes corporal.

\subsection{Etiologia}

Com s'ha dit més amunt, la malaltia de càries és multifactorial. Perquè es produïsca la lesió hi han de coexistir diversos factors: l'hoste susceptible (en aquest cas el teixit dental mineralitzat); el sucre provinent de la dieta; l'agent etiològic, és a dir, els bacteris cariogènics (els més importants: Streptococcus mutans, Lactobacillus spp, Actinomyces spp), i, finalment, el temps.

Els éssers humans estem colonitzats per bacteris potencialment cariògens. Els bacteris cariògens es transmeten, junt amb altres bacteris autòctons, de manera vertical de la mare al fill. Així, les mares amb càries actives i obertes, amb nivells alts de Streptococcus mutans, transmeten els agents patògens als seus fills per mitjà de la saliva, per la qual cosa aquests xiquets tenen major risc d'adquirir abans els microorganismes. La transmissió del Streptococcus mutans també pot ocórrer de manera horitzontal, entre membres de la família o per part dels cuidadors del xiquet, en compartir objectes o utensilis. Una manera bastant freqüent, i no per això menys desagradable, de transmissió és quan la persona encarregada de cuidar el nadó xupla el xumet per a netejar-lo abans de donar-li’l.

\section{Factors que influeixen en l'aparició de càries}

A banda de la higiene oral, hi ha dos factors primordials que influeixen en l'aparició de la lesió: la saliva i la dieta.

\subsection{Saliva}

Tant la quantitat com la qualitat de la saliva fan que aquesta hi tinga un paper fonamental. La quantitat de secreció diària oscilla entre $500 \mathrm{ml}$ i $1.000 \mathrm{ml}$, amb un volum mitjà en la boca d'1,1 ml. Durant la nit, la producció de saliva minva, de manera que en vuit hores de son es produeixen només uns $15 \mathrm{ml}$ de saliva (Walsh, 2008: 2). El pH oscilla entre 6,7 i 7,4. La saliva té diverses funcions: la lubricació, el manteniment de la integritat de la mucosa oral, la preparació dels aliments per a la deglució, la digestió oral i la fonació. A més, com a funcions relacionades amb l'aparició i protecció contra la càries, cal destacar la dilució i l'eliminació dels sucres, la capacitat tampó, la remineralització i l'acció antimicrobiana. La saliva, amb un pH 7, està sobresaturada de calci i de fosfat, la qual cosa afavoreix la remineralització de l'esmalt si el pH es manté alt suficient temps. En canvi, si el pH és àcid durant un temps considerable, es produirà la desmineralització i, amb això, la lesió de càries. En funció de la quantitat de saliva, el subjecte serà més o menys susceptible a la 
malaltia. Si la quantitat i la viscositat són adequades, hi haurà una major protecció per l'efecte d'arrossegament de les restes d'aliments que puguen quedar-se en el medi oral. Per tant, com més quantitat de saliva en repòs, major dilució dels sucres i major protecció contra la càries.

La saliva és una via esperançadora per al diagnòstic d'algunes malalties, per a controlarne l'evolució i per a la dosificació de medicaments, a causa de la facilitat d'obtenció i la relació entre paràmetres de la saliva i el sèrum (Llena, 2006: 1). Un exemple prometedor és el diagnòstic de càncer de mama, amb la presència del marcador tumoral c-erbB-2 en la saliva i sèrum de dones que el pateixen, i l'absència en dones sanes (Llena, 2006: 6).

\subsection{Dieta o substrat cariogènic}

És evident el paper de la dieta en l'aparició de la malaltia i el seu desenvolupament, tot i que la càries és, per definició, una malaltia infecciosa. Una dieta rica en hidrats de carboni augmenta la producció d'àcids i la desmineralització de l'esmalt i, per consegüent, la producció de lesions de càries. Segons l'OMS, les necessitats calòriques diàries han de cobrir-se amb una dieta rica en hidrats de carboni, entre 55\% i 75\%, dels quals el percentatge de sucres refinats no ha d'arribar al $10 \%$. El percentatge de greixos és molt menor, 15-30\%; en aquest cas, els greixos saturats no han d'abastar el 10\%. La ingesta de proteïnes recomanada està entre $10 \%$ i $15 \%$.

El consum de sucre ha augmentat en els últims temps. Mentre que al segle XVII la ingesta diària era de 12 grams i al segle XIX de 25 grams, en l'actualitat és de més de 100 grams de mitjana. Una llauna de refresc conté uns 35-40 grams de sucre, la qual cosa equival a unes 7-8 cullerades xicotetes de sucre. El nivell d'afectació de càries és més elevat en els grups de població que estan exposats a gran quantitat d'hidrats de carboni, com per exemple xiquets amb malalties que necessiten medicaments ensucrats durant llargs períodes de temps, o fins i tot els treballadors de pastisseries, els quals es mouen en un ambient ric en sucres.

Els hidrats de carboni són la principal font d'energia de les cèl·lules del nostre organisme i dels microorganismes orals responsables de la càries dental. A més d'intervenir en el procés de càries, també participen en la formació de la placa bacteriana dental, reservori de més bacteris causants de càries. Els hidrats de carboni cariogènics són, majoritàriament, monosacàrids (glucosa, fructosa i galactosa), disacàrids (sacarosa, maltosa i lactosa), oligosacàrids i polisacàrids o rents. La sacarosa és el sucre més comú en la nostra dieta i està present en diversos aliments com els caramels, fruites, begudes, cereals, productes lactis i en els preparats de tomata triturada. És el sucre que posseeix més capacitat de produir càries. La lactosa és un disacàrid resultant de la unió de glucosa i galactosa, i és el principal hidrat de carboni de la llet i derivats. Només es produeix de manera natural en la glàndula mamària. És una font d'energia fàcilment digerible pels nounats. L'enzim responsable de separar el disacàrid lactosa en els seus components és la lactasa, d'origen intestinal i també present en la placa dental bacteriana.

\subsubsection{Cariogenicitat dels aliments}

La terminologia més adequada per a qualificar el tipus d'aliment en funció de la capacitat de produir càries o no és la següent: 
- Un aliment cariogènic és el que conté hidrats de carboni fermentables que els microorganismes de la cavitat oral són capaços de metabolitzar, tot produint àcids que redueixen el $\mathrm{pH}$ de la saliva per sota del 5,5, i capaços, per tant, de produir càries.

- Un aliment cariostàtic té la capacitat de frenar o reduir la progressió natural de la lesió de càries.

- Un aliment carioprotector o anticariogènic impedeix que hidrats de carboni de la dieta s'adherisquen a la placa bacteriana i, amb això, protegeix de la càries.

- La dieta cariogènica és de consistència molla, amb gran contingut en hidrats de carboni, sobretot fermentables, que es diposita fàcilment sobre la superfície dental.

\subsubsection{Factors que estableixen la cariogenicitat dels aliments}

La capacitat cariogènica d'un aliment pot variar segons els factors següents:

\section{Propietats físiques}

- Consistència i adhesivitat: com més adherent siga l'aliment, amb major probabilitat produirà càries. Així, un caramel moll serà més nociu que un suc ensucrat. Els aliments sòlids que queden adherits a les superfícies dentals durant períodes prolongats són susceptibles de ser metabolitzats i produir àcids, fins i tot després d'haver passat una hora des de la masticació. Diversos estudis han observat, quant a la consistència dels aliments, que alguns d'aquests, encara que tinguen un contingut elevat de sucre, presenten major solubilitat i són eliminats més ràpidament de la cavitat oral, mentre que aliments amb un contingut alt en midó (pa, cereals, creïlles) poden incrementar la producció d’àcids i requerir una eliminació més lenta de la cavitat oral.

- Grandària de la partícula: com menor siga la grandària de les partícules, major probabilitat de quedar retingudes en els solcs i fissures dentals.

\section{Moment de la ingesta}

Els aliments cariogènics són menys nocius si s'ingereixen durant les menjades, ja que la saliva i els mateixos mecanismes d'autoclisi o autoneteja (el flux salival, els moviments de llengua i galtes i els moviments masticatoris) tendeixen a diluir-los i eliminar-los. A més, els sistemes tampó de la saliva tendeixen a neutralitzar els àcids que s'hi formen. El pitjor moment del dia per a ingerir aliments cariogènics és abans d'anar a dormir, ja que durant el son la producció de saliva es redueix considerablement i disminueixen els mecanismes d'autoclisi (Delgado, 2012: 16).

\section{Freqüència}

Com més vegades al dia s'ingerisquen aliments rics en hidrats de carboni, més elevat serà el risc de càries, pel fet que el descens del pH de la saliva es produirà més vegades. Transcorregudes dues hores després de la ingesta d'hidrats de carboni, el pH de la boca es recupera per l'acció tampó de la saliva, i amb això es redueix l'agressió sobre les dents. 
Aquest procés dinàmic es repeteix amb cada ingesta d'aliments. Si no es deixa temps suficient entre ingesta d'aliments, s'interromp aquest procés i s'afavoreix l'aparició de càries.

\section{Composició}

El potencial de cariogenicitat dels hidrats de carboni varia. Com s'ha llegit abans, el més cariogènic és la sacarosa. Recordem que el sucre comú és sacarosa pura. Amb menor potencial cariogènic hi ha la glucosa i la fructosa, presents en la mel i algunes fruites, i la lactosa, present en la llet i derivats. Finalment, els de menor capacitat cariogènica són els grans polisacàrids del tipus midó.

Quant al greix, se li atribueix un cert poder preventiu de la càries, ja que forma una pel-lícula sobre la superfície dental que impedeix la formació de placa bacteriana dental. Aquest fet es relaciona amb la baixa incidència de càries en població esquimal, que té una dieta molt rica en greixos i pobra en hidrats de carboni (Delgado, 2012).

\subsubsection{Influència de la dieta en la salut general i en la salut bucodental}

Qualsevol aliment que continga hidrats de carboni és un aliment potencialment cariogènic, la qual cosa no garanteix que el consumidor tindrà inevitablement la malaltia (Lipari, 2002: 13). Hi ha diversos factors que afavoriran o no l'aparició de la lesió de càries. La quantitat, la freqüència del consum i la consistència dels aliments estan íntimament relacionats amb l'aparició de la lesió. El risc de càries serà major quan s'ingerisquen grans quantitats d'aliments rics en sucres, com major siga la freqüència, quan s'ingerisquen en moments allunyats de les menjades principals i quan la consistència de l'aliment siga més apegalosa que líquida. Es pot observar la perillositat dels aliments segons la seua situació i propietats físiques (Baca i altres, 2006); es classifiquen així de major a menor perillositat:

- Aliments amb hidrats de carboni sòlids, adhesius i retentius que es consumeixen particularment entre menjades.

- Aliments amb hidrats de carboni sòlids, adhesius i retentius que es consumeixen durant les menjades.

- Aliments que contenen sucre, líquids i no retentius, consumits entre les menjades.

- Aliments que contenen sucre, líquids i no retentius, consumits durant les menjades.

La dieta és important, tant per a tenir una bona salut general com per a la salut oral. En qualsevol etapa de la vida hi ha possibilitat de patir patologia bucodental si no se segueix una dieta adequada. Açò és important en certs períodes de desenvolupament, i sembla que el període fetal és el més vulnerable (Krause i Mahan, 2013: 1157). Aquesta és la raó per la qual cal vigilar l'estat nutricional de l'embarassada, del lactant i del xiquet durant els primers anys de vida (Ferreira, 2001: 23-31). Establir unes atencions adequades durant l'embaràs i en edats infantils resulta la millor actuació preventiva contra la càries, ja que és en aquesta etapa quan s'estableixen els hàbits dietètics i higiènics que influiran al llarg de la vida. 
Hi ha evidències científiques de la relació de risc entre la desnutrició infantil amb les càries i la cronologia de l'erupció dental. D’aquesta manera, la malnutrició influeix desfavorablement en el creixement i el desenvolupament craniofacial, i és un element advers que pot afectar la formació de les dents i provocar alteracions en la forma, color i qualitat de les dents i els seus teixits de sosteniment. En casos de malnutrició infantil s'aprecia més quantitat de lesions de càries, més frequiència de gingivitis i maloclusions dentals. Hi ha defectes de l'esmalt dental associats a hipocalcèmia, dèficits vitamínics (vitamina A i D) i de minerals, de la mateixa manera que poden aparèixer defectes en l'esmalt dental secundaris a un excés o intoxicació per vitamina D, fluor i altres minerals (González i altres, 2013: 1).

El dèficit de vitamina $\mathrm{C}$ en la dieta causa la reducció d'altura dels odontoblastos, les cèlllules formadores de la dentina dental, i com a conseqüència es produeix una malformació de la dentina. De la mateixa manera, un dèficit de vitamina A durant el desenvolupament dental provoca atròfia dels ameloblastos, les cèl-lules que formen l'esmalt dental, i amb això l'aparició d'hipoplàsies de l'esmalt (Lawder i altres, 2011: 4). En els xiquets amb malnutrició proteicocalòrica de països en vies de desenvolupament s'ha evidenciat més susceptibilitat a la càries, la qual s'ha associat a una disminució d'immunoglobulina A en la saliva (González i altres, 2013: 2).

\section{Relació de la càries amb la lactància materna i artificial}

La relació entre l'aparició de càries, la llet humana i la lactància materna és altament discutida en els últims temps, de manera que són diversos els estudis que l'aborden. La càries precoç de la infància (CPI) es relaciona amb els hàbits alimentaris, a causa de l'ús prolongat del biberó o de l'alimentació materna (Vaisman i Martínez, 2004: 2). La CPI ha estat relacionada amb la lactància materna dilatada més enllà de l'any de vida (Horowitz, 1998), i la prolongada i excessiva lactància materna està associada amb càries rampant en els xiquets (Seow, 1998). Els estudis epidemiològics demostren que la llet humana i la lactància materna afavoreixen el desenvolupament físic i nutricional i impliquen avantatges psicològics, socials, econòmics i ambientals (González i altres, 2013: 3). Tanmateix, l'alimentació amb lactància materna a demanda durant la nit i continuar utilitzant el biberó després del primer any de vida es consideren factors de risc que afavoreixen la CPI (Noelle i altres, 2002).

Com ja s'ha dit, la malaltia de càries és multifactorial i és afectada per diverses circumstàncies. Es pot afirmar que menjar-se un caramel, per si sol, no produeix càries. Hi hauran de confluir diversos factors, com ara la frequiència i el moment de la ingesta, la consistència i adhesivitat del producte, la correcta o no higiene bucodental immediata, etc. Per això, alguns autors s'atreveixen a afirmar que la lactància materna no produeix càries. El mateix ocorre en la lactància amb preparats alimentaris. No obstant això, s'ha demostrat per mitjà de diversos estudis que la lactància materna, en combinació o no amb altres carbohidrats, administrada a demanda del nadó o amb una alta freqüència, sobretot nocturna, s'associa a l'aparició de càries precoces (González i altres, 2013: 3). Aquestes càries s'inicien en els incisius centrals superiors temporals, concretament en la localització on menys sovint resulten afectades les càries amb una alimentació normal en pacients de major edat, és a dir, en superfícies llises de les dents. Aquestes càries afecten ràpidament l'esmalt immadur d'aquestes dents, fins i tot quan no estan del tot erupcionades, i provoquen 
més endavant en la superfície línies horitzontals que marquen que la progressió de la càries ha transcorregut paral·lelament a l'erupció de la dent. En aquest quadre clínic característic s'aprecia, a més de l'afectació dels quatre incisius temporals maxilllars, l'absència d'afectació dels incisius inferiors, ja que estan protegits per la llengua durant els moviments de succió.

En relació al seu possible potencial cariogènic, la llet humana com a solució ensucrada és capaç de promoure la desmineralització de l'esmalt sempre que es mantinga com a substrat disponible durant vuit hores seguides, tal com ho van demostrar Thomson i altres (1996). La composició de la llet humana varia segons el període de lactància, de manera que s'adapta a les necessitats del xiquet. La llet humana conté un 7\% de lactosa, i la seua concentració augmenta a partir dels deu mesos. Durant els cinc primers mesos, la concentració de calci roman constant i disminueix a partir d'aqueix moment. Durant el primer any del període de lactància, la concentració de greix no varia. Quan la mare té dèficit d'un principi alimentari, la mamella redueix la producció de llet però no segrega llet més pobra en aqueix principi alimentari determinat. Un augment de consum d'hidrats de carboni per part de la mare no produirà canvis significatius en la concentració de lactosa i proteïnes, però sí que es produirà un augment en la concentració de greix de la llet. Resulta interessant el fet que la llet materna conté menys quantitat de greix al principi de la presa i més quantitat en la llet final. Per això és recomanable que la mare no deixe de donar d'un pit fins que note el buidament, de manera que es beneficie el xiquet amb el greix del final. Aquest greix té un efecte protector enfront de l'atac dels àcids produïts pels patògens cariogènics. Per això es desaconsella canviar de pit abans d'obtenir la llet final (Rodríguez i Pimentel, 1998: 5).

L'ús del biberó nocturn amb llet, sucs o cereals, en el bressol abans de dormir, o durant la nit, és altament perjudicial per a la salut bucodental del nadó ja que, com s'ha explicat anteriorment, durant la nit la producció de saliva minva i el pH de la saliva s'acidifica després de la ingesta d'aliments, la qual cosa propicia un ambient oral perfecte perquè els bacteris patògens produïsquen la desmineralització de l'esmalt dental. Per aquest motiu s'ha d'evitar aquest hàbit nociu i, per a substituir-lo, es pot emprar un biberó amb aigua com a element relaxant del xiquet en compte d'element nutritiu, o bé un xumet per a dormir (Tinanoff i Palmer, 2003).

És molt freqüent veure CPI en les consultes d'odontopediatria, associades a l'alimentació del nounat a demanda. L'hàbit de donar lactància materna, o lactància artificial, de manera repetida i en funció de la demanda del xiquet, comporta el risc d'aparició de les càries en edats molt primerenques. Resulta sorprenent que, fins i tot dins de la mateixa consulta dental, davant del plor del bebè, la mare o el pare li done un biberó amb l'objectiu de fer callar els plors. Per això, resulta imprescindible que el personal mèdic que atén les consultes de pediatria, metges o infermeres, conega els riscos que comporta una lactància prolongada i a demanda sense seguir uns hàbits higiènics bucodentals adequats.

\section{Prevenció de la càries precoç de la infància}

La prevenció de la CPI es basa sobretot a evitar la dieta cariogènica. No obstant això, l'educació dels pares sobre la dieta cariogènica no està massa estesa i resulta ineficaç en certs sectors de la població que tendeixen a ignorar els consells, amb la idea que les dents 
temporals es perdran i n'apareixeran altres de sanes. S'ha d'insistir en la funció primordial de les dents temporals i conscienciar els pares de la seua importància per a vèncer la manca de motivació i la resistència al canvi.

La prevenció de la CPI ha d'instaurar-se des de l'embaràs, amb revisions periòdiques al nounat per l'odontòleg (García-Suárez i Teja-Ángeles, 2008). Les intervencions preventives sobre les embarassades resulten eficaces en la reducció de l'aparició de càries en els xiquets. L'Acadèmia Nord-americana d'Odontologia Pediàtrica i l'Acadèmia Nord-americana de Pediatria suggereixen fer revisar el xiquet des del primer any per un odontòleg, a fi de reforçar l'hàbit d'higiene bucodental i promoure una alimentació adequada (Monroy, 2007). El pediatre ha de recomanar els pares que el seu fill siga visitat per un odontòleg abans de l'any de vida, ja que en rares ocasions acudeixen per iniciativa pròpia. En el primer any de vida és quan l'esmalt madura, raó per la qual és important controlar l'alimentació del xiquet amb la finalitat d'impedir l'aparició de càries i evitar possibles hipoplàsies de l'esmalt.

La higiene bucodental ha d'instaurar-se des de l'emergència de les primeres dents temporals, al voltant dels sis mesos, amb l'erupció dels primers incisius inferiors temporals. Per mitjà d'una gasa s'ha de realitzar una neteja de les dents i de l'interior de les galtes, per a eliminar restes d'aliments que puguen resultar perjudicials. Un altre sistema molt còmode d'utilitzar consisteix en un didal de silicona amb unes cerres molt fines, per mitjà del qual es pot realitzar fàcilment la higiene bucodental de les primeres dents.

A partir dels dotze mesos s'ha de començar a utilitzar un raspall de dents suau apropiat per a l'edat del xiquet, tenint en compte que el raspallat només és efectiu si és realitzat per un adult, ja que l'habilitat motora no és l'adequada. No obstant això, els xiquets aprenen per imitació, de manera que és aconsellable deixar que juguen i imiten els pares mentre aquests es raspallen les dents; a continuació, l'adult ha de realitzar

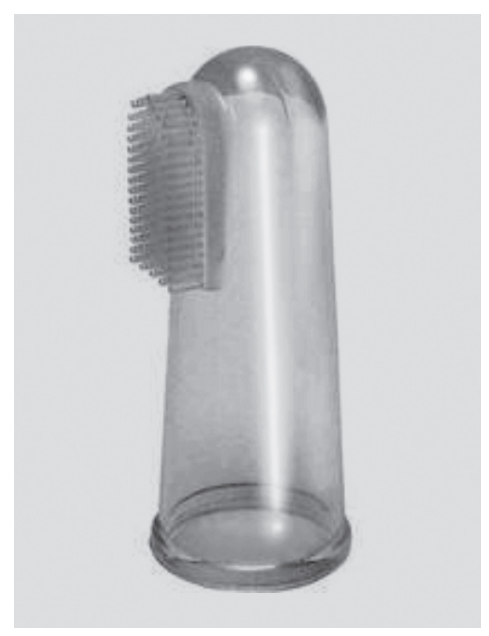

Foto 3. Didal de silicona per a higiene bucodental de bebès. el raspallat de les dents del menor. A aquesta edat, la Societat Espanyola d'Odontopediatria recomana una pasta dentífrica amb $500 \mathrm{ppm}$ de fluor, amb una molt petita quantitat sobre el raspall dental, però cal tenir en compte el control del reflex de la deglució. Entre els dos i sis anys, es recomana utilitzar una pasta de dents amb entre 1.000 i 1.450 ppm de fluor i amb una quantitat semblant a un pèsol. A partir dels sis anys es recomanen les pastes amb $1.450 \mathrm{ppm}$.

Els hàbits adquirits durant els primers anys de vida resulten difícils de modificar i estan consolidats. Els professionals sanitaris han d'ensenyar els pares a identificar els factors de risc per a la salut oral dels seus fills, transmetre'ls els coneixements necessaris per a reduir-los o eliminar-los i ajudar-los a promoure el canvi de pràctiques incorrectes. S'ha de promoure una cultura de salut bucodental en l'ambient familiar que proporcione les atencions necessàries, des dels primers anys de vida, encaminades a aconseguir una correcta nutrició i higiene bucodental dels xiquets. A més, cal intentar retardar el màxim temps possible la transmissió vertical de patògens potencialment cariògens de la mare al xiquet. 
Per a assessorar els pares sobre com poden preservar la salut oral dels seus fills, s'han de considerar les recomanacions següents:

- Explicar-los com influeix la salut oral del cuidador en la del xiquet, recomanar-los d'evitar compartir objectes que han estat en la boca de l'adult o d'altres xiquets, no xuplar tetines o culleres, ni bufar sobre aliments per a refredar-los i no besar en la boca els xiquets. Una actitud que sembla necessari eliminar, per a evitar la transmissió de patògens cariògens, és l'hàbit de netejar el xumet amb la saliva de l'adult.

- Recomanar-los que proporcionen aigua al xiquet com a beguda habitual per a calmar la set, i que eviten sucs i begudes ensucrades.

- Eliminar les begudes ensucrades i la lactància com a hàbit per a adormir el xiquet o calmar el plor.

- Promoure l'alimentació amb un ritme adequat, amb descans de qualsevol ingesta entre les preses principals.

- Prescindir del mal costum de mullar el xumet en mel, sucre o altres substàncies ensucrades.

- Evitar l'alimentació nocturna, tant de lactància materna com artificial, des de l'erupció de la primera dent.

- Vigilar els medicaments que porten sucres afegits per a millorar l'acceptació dels xiquets i els aerosols que redueixen la secreció salivar, i realitzar una correcta higiene oral després de la seua administració, siguen xarops o aerosols.

A mesura que el xiquet va creixent, cal tenir en compte, a més, altres factors: evitar els aliments que contenen sucres ocults (com els iogurts líquids, el pa de motle o les creïlles fregides), evitar picar entre les menjades principals i tenir en compte l'escala de perillositat dels aliments (sobretot els apegalosos entre les menjades).

\section{Valoracions finals}

El medi oral no pot considerar-se de manera aïllada, sinó com una part del conjunt del nostre organisme, amb interacció amb la resta de sistemes.

Dins de l'educació sanitària mereix una especial menció l'educació sanitària bucodental, ja que fa èmfasi en els aspectes nutricionals i higiènics, amb l'objectiu de prevenir l'aparició i desenvolupament de la càries. És fonamental l'educació sanitària tant de manera individual com familiar. L'atenció de la salut oral del xiquet des del naixement per mitjà d'hàbits saludables pels pares permet evitar riscos per a la salut general.

Per ser la càries una malaltia multifactorial, en la seua aparició i desenvolupament influeix un nombre complex de factors, a més del potencial cariogen de l'aliment subministrat. Resulta evident la relació entre la dieta i la salut oral. Per tant, per a aconseguir la salut oral, sembla necessari instruir els pares dels pacients de menor edat sobre la importància d'uns hàbits tant dietètics com higiènics bucodentals.

De la mateixa manera, el personal sanitari que atén les consultes de pediatria ha de conèixer els factors de risc de la càries precoç de la infància, ser conscient del seu paper en l'educació de la salut bucodental i ser capaç de conscienciar els pares sobre les mesures 
higienicoalimentàries convenients per als seus fills, amb la finalitat de preservar la salut oral. El mateix personal sanitari pot contribuir a prevenir la càries precoç de la infància identificant els patrons alimentaris d'alt risc i explicant els pares les opcions de canvi de dieta a fi de reduir el risc d'aquesta malaltia prevalent.

\section{BIBLIOGRAFIA}

American Academy of Pediatric Dentistry (2006): «Definition of early childhood caries (ECC)», Pediatric Dentistry, 27, 13.

BACA GARCíA, P. i altres (2006): Cuaderno virtual de prácticas de odontología preventiva y comunitaria. Dieta y nutrición, Granada, Universidad de Granada.

Berkowitz, R.J. (2003): «Causes, treatment and prevention of early childhood caries; a microbiologic perspective», Journal Canadian Dental Association, 69, 304-307.

Bravo, M. i altres (2007): «Encuesta de Salud Oral de Preescolares en España 2007», RCOE, 12 (3), 143-168.

Clarke, M. i altres (2006): «Malnourishment in a population of young children with severe early childhood caries», Pediatric Dentistry, 28 (3), 254-259.

Consellería de Sanitat (1986): Estudio de Salud Bucodental Infantil en la Comunidad Valenciana, València, Conselleria de Sanitat.

- (1998): Estudio de Salud Bucodental Infantil en la Comunidad Valenciana, València, Conselleria de Sanitat.

- (2004): Estudio de Salud Bucodental Infantil en la Comunidad Valenciana, València, Conselleria de Sanitat.

- (2010): Estudio de Salud Bucodental Infantil en la Comunidad Valenciana, València, Conselleria de Sanitat.

Delgado Loyola, S.S. (2012): Alimentos cariogénicos, colación escolar y comida chatarra relacionada con la incidencia de caries dental y su prevención, en los niños/as de 6 a 10 años de edad de las escuelas fiscales mixtas: Ingeniero Velasco, Astudillo, Ordoñez, de la ciudad de Loja durante el periodo febrero-julio 2012, tesi doctoral, Loja, Universidad Nacional de Loja (Ecuador).

Ferreira, F.P. i A.A. Osmo (2001): Nutriçao da criança. Odontopediatria na primera infància, Sao Paulo, Santos.

GonZÁLez SAnZ, A.M. i altres (2013): «Salud dental: relación entre la caries dental y el consumo de alimentos», Nutrición hospitalaria, 28, 64-71.

García Rodríguez, I. i altres (2006): «Manifestaciones bucales de la infección del VH/SIDA», Revista Médica electrónica, 28, <http://www.revmatanzas.sld.cu/revista\%20medica/ano\%202006/vol6\%20 2006/tema15.htm>.

García-Suárez, A. i E. de la Teja-Ángeles (2008): «Caries temprana de la infancia. Prevención y tratamiento. Presentación de un caso», Acta Pediátrica de México, 29 (2), 69.

Gussy, M. i altres (2006): «Early childhood caries: current evidence for etiology and prevention», Journal Paediatric and Child Health, 42 (1-2), 37-43.

Herzberg, M.C. i altres (1992): «The platelet interactivit phenotype of Streptococcus sanguis influences the course of experimental endocarditis», Infection and Immunity, 60, 4809-4815.

Horowitz, H.S. (1998): «Research issues in early childhood caries», Community Dentistry Oral Epidemiology, 26, 67-81. 
Krause, M.V. i L.K. Mahan, (2013): Alimentos, nutriçao e dietoterapia, Sao Paulo, Roca.

LAWDER, J. i altres (2011): «Análisis del impacto real de los hábitos alimenticios y nutricionales en el desarrollo de la caries dental», Acta odontológica venezolana. Revista latinoamericana de Ortodoncia y Odontopediatría, 49, 2.

Llena Puy, C. (2006): «La saliva en el mantenimiento de la salud oral y como ayuda en el diagnóstico de algunas patologías», Medicina oral, patología oral y cirugía bucal, 11, 449-455.

Matilla, K.J. (1989) «Association between dental health and acute myocardial infection», British Medical Journal 298, 779-781.

Milnes, A.R. (1996): «Description and epidemiology of nursing caries», Journal Public Health Dental, $56,38-50$.

Monroy P.G. (2007): «The age-1 dental visit and the dental home; a model of early childhood caries prevention», Journal of the Michigan Dental Association, 89 (1), 3234-3236.

Moromi Nakata, H. (2004): «Bacterias orales y enfermedades sistémicas: una revisión», Odontología sanmarquina, 8,1 .

NoElLe, L.H. i K. Joon (2002): «Caries-risk factores for hispanic children affected by early childhood caries», Pediatric dentistry, 24 (6), 536-542.

Organización Mundial de la SAlud (2007): «Salud Bucodental», 318.

PeÑa Sisto, M. i altres (2008) «La enfermedad periodontal como riesgo de enfermedades sistémicas», Revista cubana de estomatología, 45, 6.

Pretel-Tinoco, C. i B. Chávez Reátegui (2013): «Periodontal Disease as a Risk Factor for systemic conditions», Revista Estomatología Herediana, 23 (4), 223-229.

Rodríguez, M. i E. Pimentel (1998): «¿Puede la leche humana llegar a producir caries: por qué y cómo?», Acta Odontológica venezolana. Revista latinoamericana de Odontología y Odontopediatría, 36 (1), 39-45.

SEow, W.K. (1998): «Biological mechanisms of early childood caries», Community Dental Oral Epidemiology, 26, 8-27.

Thomson M.E. i altres (1996): «In vitro and intra-oral investigations into the cariogenci potential of human milk», Caries research, 30, 434-438.

Tinanoff, N. i C.A. PALmer (2003): «Dietary determinants of dental caries and dietary recommendations for preeschool childen», Refuat hapels vehashinayim, 20 (2), 8-23.

VAisman, B. i M.G. Martínez (2004): «Asesoramiento dietético para el control de caries en niños», Revista latinoamericana de Ortodoncia y Odontopediatría,

$<$ http://www.ortodoncia.ws/publicaciones/2004/art10.asp>.

WaLsh, L. (2008): «Aspectos clínicos de biología salival para el clínico dental», Revista de Mínima Intervención en Odontología, $1,1$.

\section{BIONOTA}

\section{Anna Verdegal Burdeus}

(Borriana, 1981) Llicenciada en Odontologia per la Universitat de València (2004). Postgrau en Ortodòncia. Postgrau en Cirurgia i Implantologia. Màster en Sostenibilitat Sanitària mitjançant la Gestió Innovadora dels Recursos. Màster en Diagnòstic per la Imatge. Màster de Medicina Regenerativa i Antienvelliment. Actualment treballa d'odontòloga al Centre de Salut Integrat de Benicarló, on és coordinadora de la Unitat d’Odontologia Preventiva. Compagina aquesta tasca amb la pràctica privada. 